\title{
(UN)INTENDED CONSEQUENCES OF THE BIG SOCIETY FOR SOCIAL ENTERPRISE ORGANISATIONS
}

\author{
Ciaran Connolly and Martin Kelly \\ Queen's University Belfast
}

\begin{abstract}
$\mathrm{T}$

his paper draws upon institutional and legitimacy theories to consider whether the Big Society may lead to unintended consequences for social enterprise organisations (SEOs). Policy pressures are forcing not-for-profit organisations (NFPOs) to become more business-like through the social enterprise model. However, in doing so, NFPOs risk 'mission drift', with their traditional roles being threatened due to capacity constraints. Moreover, there are concerns that the increasing privatisation of public services may crowd out genuine SEOs. While focusing on SEOs operating in the United Kingdom, the issues raised are also pertinent to academics and policy-makers within the Republic of Ireland.
\end{abstract}

\section{INTRODUCTION}

While the term 'social enterprise' has come to the fore more recently, defining it is fraught with difficulties. Although the literature provides a range of definitions, the concept remains pluralistic, contextual and contested. Indeed, Kerlin (2010) concluded that not only do different countries adopt alternative definitions of social enterprise, but that even broader divisions exist in terms of the understanding, use, context and policy for social enterprise. This paper contributes to this debate by discussing social enterprise in the context of the public, for-profit and not-for-profit sectors and developing two models to illustrate this. Moreover, drawing upon institutional and legitimacy theories, together with the concept of marketisation, the paper considers whether the Big Society agenda, a key tenet of the United Kingdom (UK) Coalition Government's vision for reforming public services, may lead to unintended consequences for social enterprise organisations (SEOs). With respect 
to the Big Society, while there is debate about how it is operationalised, in broad terms it involves empowering communities, encouraging social action and opening up public services (House of Commons, 2012). Regarding SEOs, which are the heart of the Big Society, these are organisations which use business to tackle social problems, improve people's life chances and protect the environment. However, as institutional theory suggests that organisations will adopt the practices of those that dominate, there is the possibility that, in time, SEOs may resemble for-profit organisations.

The not-for-profit (NFP) sector consists of a variety of different organisations. ${ }^{1}$ In the UK, charities play a dominant role within the sector and have a long history of making a vital contribution to society, one which has been enhanced in recent years as more and more have become engaged in the design and delivery of public services. The current high esteem in which UK charities are held can, at least in part, be attributed to actions taken following a report by Bird and Morgan-Jones (1981), which identified significant failings in charity reporting that if left unchecked had the potential to undermine trust in the sector. As a result, a number of steps, both regulatory and voluntary, were taken to encourage and promote accountability within the sector. These included the development of a Statement of Recommended Practice (SORP) on charity accounting. The first charity SORP was issued in 1988, with subsequent iterations in 1995, 2000 and 2005. Other drivers include the publication of Private Action, Public Benefit: A Review of Charities and the Wider Not-for-Profit Sector (Strategy Unit, 2002), which called for the sector to develop greater accountability and transparency to build public trust and confidence, together with the publication/revision of charity legislation and the establishment/strengthening of regulatory bodies to oversee, promote and encourage accountability within the sector. $^{2}$

In terms of the format of the paper, the next section places the Big Society in its historical context. Then, after defining the term 'social enterprise', the role of SEOs is considered and the blurred boundaries between NFP and for-profit organisations with respect to the provision of public services are discussed. After that, government policy in relation to the promotion of social enterprise is considered in the context of the Big Society and, utilising institutional and legitimacy theories, possible reasons for both NFP and for-profit organisations embracing the social enterprise model are suggested. Finally, the (un)intended consequences of the Big Society agenda for SEOs are assessed before the paper concludes.

\section{THE RATIONALE FOR THE BIG SOCIETY}

Most countries around the world recognise the importance of the NFP sector in the development and delivery of welfare provision. Since the 1980s UK governments have attempted to create more efficient markets for public goods by opening up the market for the delivery of public services to providers from the private and NFP sectors on a 'best value' basis (Newman, 2007). This process accelerated under New Labour, with a considerable expansion of government support for the sector and NFPOs being given an enhanced role in economic policy (Haugh and Kitson, 2007). 
This support included major new programmes of 'horizontal' funding which aimed to provide funding for organisations across the sector, contrasting with previous policies which had often focused on 'vertical' streams linked to particular service areas (Alcock, 2011). Often referred to as the 'third way' (Giddens, 1998), this represented a step change in government support for the NFP sector and it led to an unprecedented political and economic profile for the sector (Alcock and Kendall, 2011). Although the term 'third way' lacked clarity and fell out of favour, policies associated with it included repositioning the state as a guarantor, not necessarily a provider, of public services, and emphasising mutualism, active governance and accountability (Gover, 2009). The establishment of an Office for the Third Sector ${ }^{3}$ in May 2006 marked the political acceptance, and social construction, of the NFP sector as a distinct grouping with its own identity and rationale.

While the NFP sector policy developed by New Labour is still being evaluated, it is considered to have introduced a new spirit of partnership with government leading to a new-found 'strategic unity' across the sector based on a closer commitment to policy engagement (Alcock, 2010). However, some argue that with the increased support came new problems, not least the shift towards greater use of contracts for services with all their attendant regulatory and accountability frameworks, leading to a fear that independence could be challenged by incorporation and isomorphism (Smerdon, 2009).

Since 2010, there has been a policy shift under the UK Coalition Government. This has taken the form of a new policy discourse centred on the desirability of promoting the Big Society, to be contrasted with the 'Big Government' that New Labour had supposedly advanced. This would bring about changes in the relationship between government and citizens, in particular by shifting the balance of government support for voluntary and community action. However, the danger in viewing things through a neoclassical lens that excludes the possibility of behaviour not bound by market exchange and rational choice is the risk of creating a world which loses sight of values such as reciprocity and philanthropy (Tsakalotos, 2005). Viewing NFPOs through this lens has valorised commercial revenue (Eikenberry, 2009) and, as a consequence, it is argued that NFPOs are behaving more like businesses in replacing traditional sources of revenue with commercial revenue because they are expected, or even compelled, to do so, rather than from a rational assessment of the financial and social implications (Dart, 2004; Eikenberry and Kluver, 2004).

This recognition of the NFP sector and the growing emphasis being placed upon civil society (i.e. civic engagement and involvement) and social capital (i.e. connections among individuals) are reflected in the Big Society, an ideology driven by the vision of the UK Coalition Government to redefine and transform the relationship between the state and its citizens. Indeed, it is argued that the title 'Office for Civil Society' (rather than 'Third Sector') is consistent with the broader concept of a Big Society. Although, perhaps unlike the term 'third sector', the notion of a 'civil society' is more of a theoretical idea rather than a way of classifying organisational forms (Evers, 2010).

In May 2010, at the launch of the Big Society programme, the UK Coalition Government announced that social enterprise was at the heart of its reform of public 
services as part of the Big Society agenda. The Cabinet Office (2010) subsequently published its strategy to support and strengthen the NFP sector so that NFPOs could realise the opportunities being made available as part of the Big Society. Specific policy initiatives include a commitment to make it easier to set up and run charities, SEOs and voluntary organisations; and giving public sector workers the right to form employee-owned cooperatives to deliver public services (Cabinet Office, 2010). In essence, the Big Society is about community empowerment (giving local councils and neighbourhoods more power to take decisions and shape their areas), social action (encouraging and enabling people to play a more active role in society) and public service reform (opening up public services to enable NFP and for-profit organisations to compete to offer high-quality services). This is reflected in the publication of the Open Public Services White Paper in July 2011 (Open Public Services and Cabinet Office, 2011), which sets out the principles on which the Coalition Government's plans for modernising services are based: increase choice, decentralise power to the lowest appropriate level, open public services to a range of providers, ensure fair access to public services, and make public services accountable to users and taxpayers. It is intended that the combined effect of these principles will place power in the hands of individuals and local communities where appropriate, with people being able to choose the type of service they want and find the best provider to meet their needs.

The Big Society is not a new concept. For example, notions of social action and community empowerment can be traced back to Edmund Burke, an Irish philosopher and politician, who arguably personifies the philosophy and spirit of the current UK Coalition Government. While Burke was not an enemy of the state, he was passionately opposed to the idea that the state had a 'carte blanche' on which a supposedly rational government could scribble whatever it wished. Although Burke never used the term 'Big Society', its principles are present in his Reflections on the Revolution in France: 'to be attached to the subdivision, to love the little platoon we belong to in society, is the first principle (the germ as it were) of public affections' (Burke, 1790). Burke believed that by providing a focus for allegiance and affection, and strengthening our sense of belonging, the 'little platoons' help us to know who we are and what is expected of us. The potency of his views is encapsulated in his belief that 'society is indeed a contract .... [It is] a partnership not only between those who are living, but between those who are living, those who are dead, and those who are to be born' (Burke, 1790).

Indeed, the commitment to open up public services to mutuals and cooperatives links the Big Society to the cooperative movement, first established in Rochdale in 1844 (House of Commons, 2012). Consistent with the views expressed by Burke, Co-operatives UK (2010, p. 3) believes that 'what makes the co-operative approach important is that it's a way of doing things that makes it possible to harness the drive human beings have to achieve their goals by acting together.' The Big Society has also been linked to social action in alienated communities in 1930s Chicago, where the aim was that poor local communities would generate power and build relationships through their own leadership and setting their own agenda.

The current Big Society project also has roots in the theory of social capital, most notably espoused by Putnam (1995, p. 69) who argues that declining memberships 
in civic institutions such as bowling leagues, the League of Women Voters and the Boy Scouts have led to a weakened civil society and the development of 'a widespread tendency towards passive reliance on the state'. While Putnam's work is not without criticism (Tarrow, 1996; DeFilippis, 2001; Patulny, 2004), the broader social significance of this, Putnam argues, lies in the social interaction and civic conversations over beer and pizza that solo bowlers forgo. A weak civil society means less 'trust' in each other and consequently a less vigorous democracy, as evidenced in declining electoral turnouts. In contrast, Putnam believes that greater engagement in the local community has wider benefits for society.

Norman (2010) links the Big Society ideals with the work of Michael Oakeshott, an English philosopher and political theorist, who identified two competing types of society or human relations: civil association and enterprise association. In the latter, individuals are related by their agreement to cooperate in pursuing some substantive end, for example, to make money by selling a product. In contrast, members of a civil association have no such common goal; they are connected by their recognition of a body of law that delimits the acceptable means through which they can pursue their own, diverse goals. Oakeshott supported those who advocated that the role of the state was to promote civil association.

David Cameron, before he became Prime Minister of the UK Coalition Government in 2010, outlined his theory of the Big Society, and why it was his answer to a 'broken society'. In his speech to the Conservative Party Conference in October 2009, he stated, 'So no, we are not going to solve our problems with bigger government. We are going to solve our problems with a stronger society' (Cameron, 2009a). Further details emerged in Mr Cameron's Hugo Young lecture in November 2009, when he called for 'state action' to make the Big Society project a reality: 'Our alternative to big government is not no government .... Our alternative to big government is the Big Society' (Cameron, 2009b).

\section{SOCIAL ENTERPRISE ORGANISATIONS: BLURRED VALUES AND BOUNDARIES}

The term 'social enterprise' is wide-ranging and can capture equally well organisations that seek to create employment opportunities for people with learning difficulties or mental health problems, regenerate disadvantaged areas, or resemble large commercial organisations whose surpluses (however defined) are distributed for social benefit. In simple terms, SEOs are organisations driven by a social and/ or environmental mission, and they are becoming an increasingly important feature of the public policy landscape both in the UK and internationally (for a discussion of the key concepts of social enterprise, see Teasdale (2010a)). In different countries the social enterprise model has become popular with policy makers and politicians alike as it combines elements of the market, state and civil society, and appeals to interests on all sides of the political spectrum (Kerlin, 2010). For many, SEOs have the ability to offer an alternative approach and ethos to public service delivery compared with traditional for-profit and public sector organisations. Indeed, seen as a solution to many of society's failures (Nicholls, 2006), SEOs are being actively 
encouraged to play a greater role in the delivery of public services, examples of which can be found in the provision of leisure facilities, recycling services and health and social care provision. They reflect a new kind of organisational model, one which differs from traditional NFPOs largely because of their focus on trading. An example of an organisation that has made the transition from being a charity to an SEO is Bryson House in Northern Ireland (NI). However, unlike traditional trading organisations, its main objective is not profit maximisation for shareholders but rather the satisfaction of social needs under the constraint of economic sustainability. In the current difficult economic climate, SEOs, such as Bryson House, play a pivotal role in economic regeneration, social inclusion and the delivery of public services.

While the exact scale and scope of social enterprise is a matter of debate, partly due to definitional issues (see below), it is estimated that there are approximately 62,000 SEOs in the UK, contributing $£ 20$ billion to the economy and employing over one million people (Social Enterprise Coalition, 2011). Under the Big Society agenda, the SEO model is being promoted as a blueprint for organisations to generate economic value in a manner that serves a social purpose. With the UK government seeking to open up public sector procurement, SEOs can play a vital role in delivering critical public services and driving forward economic regeneration. For example, KPMG was commissioned by government to undertake an evaluation of the NI social economy. Among the recommendations of the KPMG (2011) report was that the strategy for the social enterprise sector should be an integral component of the overall NI economic strategy. Furthermore, in 2012, the Department of Enterprise, Trade and Investment (NI) and the Department of Social Development (NI) appointed a firm of consultants to undertake a scoping exercise on the size and scale of the NI third sector and to assess the potential of community and voluntary organisations making the transition to the social enterprise model. The final report was published in January 2014 (Murtagh, Goggin and McCrum, 2014).

Peattie and Morley (2008) suggest that SEOs are distinguished from other organisations by two attributes: the primacy of their social aims, and their trade in goods and services in the market place. These attributes are clearly evident in the definition adopted by the Social Enterprise Coalition (2011), the UK's representative body for SEOs, which refers to an SEO as a business that trades for social and environmental purposes. Similarly, the Department of Trade and Industry (2002, p. 7) defines an SEO as 'a business with primarily social objectives whose surpluses are principally reinvested for that purpose in the business or in the community, rather than being driven by the need to maximise profit for shareholders and owners'. This means that an SEO does not exist for the primary purpose of creating shareholder profit, but rather reinvests its surplus to achieve a specified social aim. As the primacy of the social mission over all other organisational objectives is key, this enables the inclusion of NFP and for-profit organisations with social objectives as SEOs.

Traditionally, it is perceived that NFPOs are responsible for creating social value and for-profit organisations for creating economic value (Figure 1); social enterprise brings together these dichotomies, integrating social interest and market systems to create both social and economic value. Therefore, for many organisations, 
particularly those with roots in the NFP sector, the adoption of the social enterprise model is viewed as a strategy to diversify their funding base, decrease reliance on donors and recover costs of social programmes. One way of presenting NFP and for-profit organisations is to consider them at opposite ends of a continuum with SEOs falling somewhere in between (Dees, 1998). Figure 1, which illustrates the drift from traditional NFP to for-profit organisation and vice versa, locates SEOs on the social value side of the continuum, more aligned to the values of NFP than for-profit organisations. In this context, SEOs are 'hybrids' choosing from a range of social and economic activities and utilising various organisational forms.

FIGURE I:THE SOCIAL ENTERPRISE CONTINUUM

\begin{tabular}{|c|c|c|c|c|c|}
\hline \multicolumn{6}{|c|}{ Emergence of social enterprise models } \\
\hline $\begin{array}{c}\text { Traditional } \\
\text { NFPO }\end{array}$ & $\begin{array}{l}\text { NFPO with } \\
\text { income } \\
\text { generating } \\
\text { activities }\end{array}$ & $\begin{array}{c}\text { NFPO funded } \\
\text { mainly by } \\
\text { market trading } \\
\text { generating } \\
\text { activities }\end{array}$ & $\begin{array}{c}\text { Socially } \\
\text { responsible } \\
\text { business }\end{array}$ & $\begin{array}{l}\text { For-profit } \\
\text { organisations } \\
\text { practising } \\
\text { social } \\
\text { responsibility }\end{array}$ & $\begin{array}{c}\text { Traditional } \\
\text { for-profit } \\
\text { organisations }\end{array}$ \\
\hline
\end{tabular}

Given the promotion of the social enterprise model by government for 'its effective delivery of public services and for making NFPOs more financially self-reliant' (Hardy, 2004, p. 39), it is conceivable that NFPOs are being driven towards the economic end of the continuum. However, Defourny and Nyssens (2006) highlight the tensions that can arise when organisations try to balance an NFP ideology with a market mindset, while Dart (2004) describes social enterprise as a 'blurring' between the NFP and for-profit sectors. Indeed, the debate about developing a more business-like perspective and moving to an SEO model is becoming an increasingly salient issue for NFPOs, particularly with donation and grant income being reduced in the current economic climate and the subsequent need to develop alternative sources of income.

At the present time, governments require innovative solutions to address growing pressures such as the ageing society, climate change and the rise of lifestyle-related long-term health conditions. Within the public sector, encouraged by New Public Management ideas (Hood, 1995), social enterprise models are being promoted to deliver public services with both NFP and for-profit organisations being attracted towards such opportunities. This fits with the idea of the state taking on a role of enabler rather than a direct provider of public services and, because of its institutional features, the social enterprise model opens up new productive opportunities which are best suited to the supply of quasi-public and meritorious goods. For example, because of their objective of combining social values with trading, SEOs can create trust with customers, thereby reducing the costs of contracts linked to asymmetric information. The public benefit nature of these organisations facilitates the spread of benefits beyond mere market transactions to weak groups and the community at large. Many of these ideas have their roots within the ideology 
of the Big Society where social enterprise is increasingly seen as a key part of the reform of public services.

If the continuum (Figure 1) is broadened to explicitly incorporate a public sector dimension (Figure 2) SEOs can be considered to have developed across the NFP, for-profit and public sectors in many forms (for example, trading charities, development trusts and social firms) (Pharoah, Scott and Fisher, 2004; Ridley-Duff, 2008). A different type of SEO exists at each cross-section, with the ideal type being located at the crossover point of all three sectors.

FIGURE 2: CROSS-SECTOR MODEL

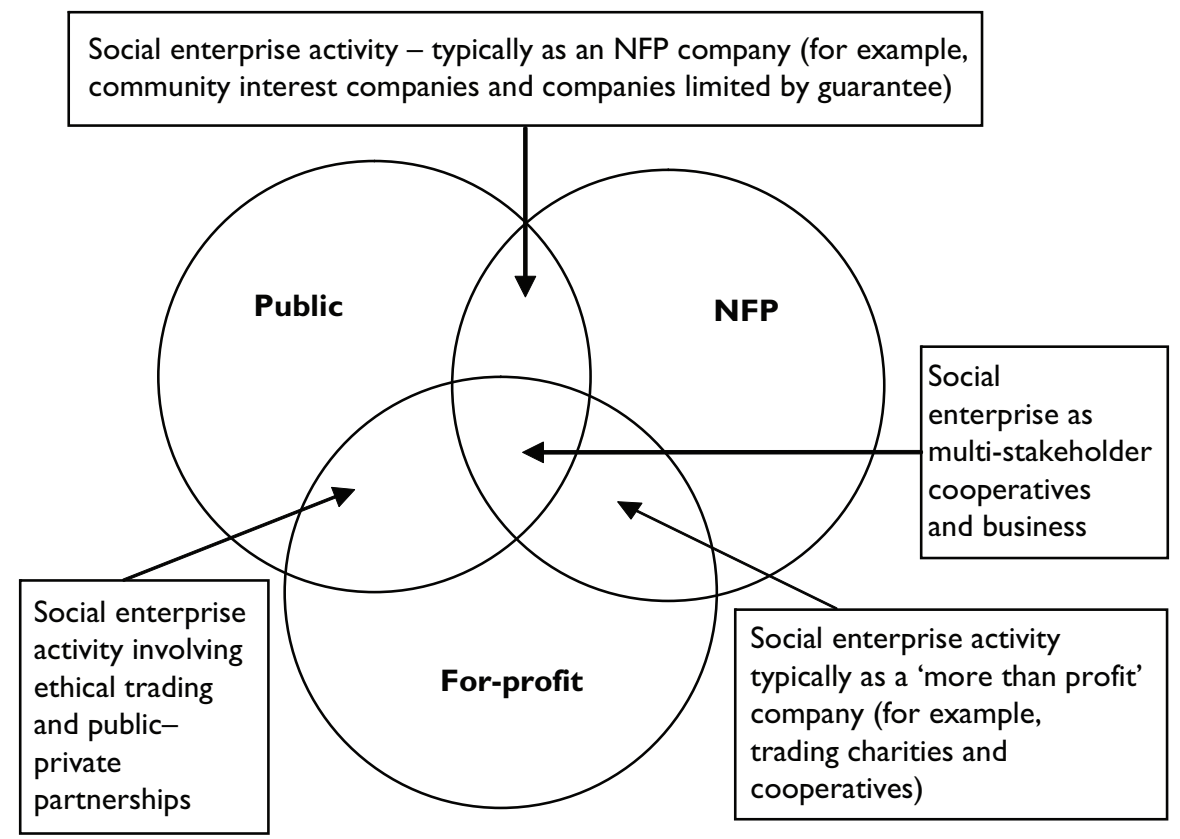

Indeed, Nicholls (2006) limits 'social enterprise' to the point where all three sectors overlap. The advantage of placing SEOs within a 'lumpy' landscape (Aiken, 2006) is that the cross-sector model promotes an understanding not only of likely trading activity but also of the ambiguity, origins, ethos and characteristics of social enterprise activity (Pharoah et al., 2004; Seanor and Meaton, 2007).

Given the blurring of the boundaries between the three sectors and responsibility for public service delivery, there is a danger the social enterprise movement will be hijacked by traditional for-profit organisations jumping on the social enterprise bandwagon. Indeed, one of the final acts of the Labour administration before the 2010 general election was to widen the social enterprise construct to incorporate mainstream businesses with a social conscience (Teasdale, 2010b). Moreover, the broader title of Office for Civil Society (see earlier), rather than the more clearly defined Office for the Third Sector, perhaps illustrates a desire to blur the boundaries between sectors to provide a larger space for the Big Society and social enterprise to develop. In fact some, including Harding (2010), are promoting a move in the UK to 
recognise mainstream for-profit businesses as social enterprises, with the risk being that, as the policy construct develops, any defining characteristics are reduced to trading for a social purpose (Peattie and Morley, 2008).

\section{TOWARDS LEGITIMATION OF THE SOCIAL ENTERPRISE MODEL FOR PUBLIC SERVICE DELIVERY}

The capitalist system is under enormous pressure and for-profit organisations are increasingly being viewed as a major contributor to social, environmental and economic problems. The social contract with business is in a state of flux and questions have been raised over the 'legitimacy' of business which is perceived as having a narrow short-term financial performance focus. Friedman's (1962) influence and the ideology of shareholder value reinforce each other and cater to only one constituency - shareholders. Friedman contends that neither should government be the patron of an individual, nor should that person consider themselves a servant of the government. He argues that, in a real democracy, the nation exists only for the will of the people and that government is a means towards an end, nothing more. Making a clear connection between economic freedom and political freedom, Friedman asserts that free markets are not a luxury but the very basis of personal and political liberty.

In contrast, Porter and Kramer (2011) argue that traditional for-profit organisations must reconnect with society in order to develop a principle of 'shared value', which involves creating economic value in a way that simultaneously creates value for society. In this respect, SEOs, because they are not constrained by narrow shortterm traditional managerialist objectives, are ideally placed to deliver profitable solutions to social problems. Therefore, the Big Society and its promotion of social enterprise could be a means by which for-profit organisations regain legitimacy. Porter and Kramer argue that business and society have been pitted against each other for too long, in part because neoclassical economists, such as Friedman, have legitimised the idea that to provide societal benefits, companies must temper their economic success. They believe that a company's social responsibility happens through the sustained success of business activities that simultaneously generate business and social value. Indeed, Chang (2011, p. 252), referring to the recent financial crisis, suggests that the fundamental theoretical and empirical assumptions behind free market economics are highly questionable, although Aakhus and Bzdak (2012) question whether the shared value concept has progressed much beyond the $1950 s^{\prime}$ mantra that 'what is good for business is good for society.'

Based upon the previous discussion, and as illustrated in Figures 1 and 2, NFP and for-profit organisations may seek to legitimise their activities by aligning themselves with the values of social enterprise. In attempting to understand the emergence of social enterprise as a new organisational form within the NFP and for-profit sectors, institutional theory is a useful framework to help understand the social enterprise domain. Institutional theory is concerned with exploring the way an organisation relates to its environment, and its reasons for adopting certain structures, cultures, routines and practices (Scott, 1995). Organisations find value 
in compliance with institutional expectations, because through such compliance they receive the prestige, stability, access to resources and social acceptance they require in order to survive (Meyer and Rowan, 1977). As the social enterprise model evolves there is likely to be more emphasis on market orientation for income generation, with a normative ideology surrounding market-based solutions becoming pervasive in the thinking and management of NFPOs (Eikenberry, 2009).

Indeed, in the 2010 Queen's Speech, the UK Coalition Government pledged to support the growth of social enterprises, open up public sector markets and enable public sector workers to form employee-owned cooperatives. Then, in February 2012, the Public Services (Social Value) Act was passed, requiring all public bodies in England and Wales to consider how the services they commission and procure might improve the economic, social and environmental well-being of the area. The core aim of the Act is to ensure that government and local authorities publish strategies to promote and enhance social enterprise. While NFPOs and SEOs are those most likely to benefit since they already explicitly work to create social value, for-profit organisations can be expected to bid for public service contracts and demonstrate similar social credentials. However, Edwards (2008, p. 49) argues strongly that marketisation 'has the potential to endanger the most basic value of the NFP sector - availability of "free space" within society for people to invent solutions to social problems and serve the public good'.

There are wider societal pressures at work within the for-profit sector which are casting doubt on the appropriateness of the traditional shareholder value model. Thus, for-profit organisations may seek legitimacy by moving towards social enterprise (Figure 1). Rather than view the NFP sector as a rational response to failures in the market or state (Salamon, 1995), institutional theory offers explanations for the emergence of social enterprise that are more sociological. Changing societal expectations in terms of delivering goods and services in a more sustainable way has become a powerful force for paradigm change in how the distinction between forprofit and NFP sectors is viewed. Indeed, it could be argued that the Big Society agenda will encourage NFP and for-profit organisations to become SEOs, arguably for different reasons. In the context of institutional theory analysis of SEOs, Dart (2004, p. 415) noted:

From an institutional perspective, legitimacy is ... the means by which organisations obtain and maintain resources ... and is the goal behind an organisation's widely observed conformance (or isomorphism) with the expectations of key stakeholders in their environment.

The institutional legitimacy perspective emphasises sector-wide dynamics that are beyond the purposive control of any single organisation. On this basis, managers will react to changes in their environment to make their organisations respond (conform) to societal expectations. This can promote organisational legitimacy (in for-profit organisations) and bring further benefits in terms of additional resource streams (for NFPOs). Clearly, for SEOs, the establishment and maintenance of credibility and trust with a wide range of stakeholders is critical to their right to operate. In addition, the social enterprise model could enhance organisational legitimacy because it enables access to resources and gives certain stakeholders 
social acceptance. Indeed, the government may find these organisations legitimate because they offer innovative solutions to social problems and may indicate that the Big Society is also about legitimising funding cuts.

In the context of SEOs, Dart (2004) highlights three levels of legitimacy: pragmatic, moral and cognitive. Pragmatic legitimacy involves external stakeholders asking the questions, what am I getting from this organisation and does it meet my expectations? In contrast to pragmatic legitimacy, Suchman (1995) suggests moral legitimacy is based on normative estimations of whether an organisation fits accepted societal frameworks of behaviour or not. In effect, moral legitimacy is accorded to SEOs that mimic free market models because of the acceptability of the ideological principles associated with social enterprise. With respect to cognitive legitimacy, it is unthinkable for the organisation to be anything other than what it is. On this basis, an organisation is legitimate because it is accepted or taken for granted that its intentions are noble. Arguably this applies to well-known NFPOs, with institutional theory supporting the notion of organisations seeking to achieve this form of legitimacy.

DiMaggio and Powell (1983) identify three mechanisms through which institutional isomorphic change occurs, each with its own antecedents: (a) coercive isomorphism that stems from political influence and problems of legitimacy. This type of isomorphism results from the formal and informal pressures exerted by other organisations on which organisations are dependent and by cultural expectations in the society in which the organisations operate; (b) mimetic isomorphism resulting from standard responses to uncertainty; and (c) normative isomorphism associated with professionalisation and norms that are both internalised and imposed by others (Scott, 1995). Moral legitimacy is therefore closely associated with isomorphic pressures from society and other key stakeholders to which managers often conform. In other words, moral legitimacy reflects a type of mimetic isomorphism that leads to SEOs copying established business practices.

Within the for-profit sector a form of coercive isomorphism can be observed, as evidenced by the questioning of the traditional maximisation of shareholder value model. The legitimacy of for-profit organisations has been questioned and change is being imposed, albeit slowly, by societal expectations and powerful political and academic voices. According to Porter and Kramer (2011), corporations are now being coerced into adapting new business practices which better connect with and meet social expectations. It may be the case that, in terms of reporting and evaluating performance measures such as social return on investment, the for-profit sector may itself begin to emulate, over time, the practices operated by successful SEOs. Of course, it may be that these organisations are putting in place particular processes purely to impression manage certain aspects of legitimacy, as being perceived as an SEO may enhance organisational legitimacy and bestow more favourable treatment from funders and customers (Teasdale, 2010a). In other words, the resulting institutional image can sometimes be more apparent than real.

Recent developments in terms of the Big Society (together with government spending cuts) have increased the ambiguity surrounding the identity of organisations that operate within the NFP sector. It could, however, be argued that SEOs bring with them a moral legitimacy that belies the need for mimetic behaviour, even 
in a period of instability and uncertainty. Therefore the focus on being part of the Big Society and obtaining legitimacy may result in both NFP and for-profit organisations converging towards the social enterprise model for very different reasons.

\section{(UN)INTENDED CONSEQUENCES}

Although the literature provides a range of definitions of what social enterprise is (Defourny and Nyssens, 2006; Peattie and Morley, 2008), the concept remains contentious. It is within this context that this paper explores the (un)intended consequences of the Big Society for SEOs and their implications for policy makers. To date, there has been little attempt within the academic literature to connect organisational theories with major policy pronouncements in the context of SEOs. This paper contributes to the theoretical debate by utilising institutional and legitimacy theories to consider whether the policies designed to deliver the Big Society values may lead to unintended consequences for SEOs.

As discussed earlier, there is ambiguity as to what the term 'social enterprise' actually means and a lack of understanding of the organisational model. This, in combination with the blurring of the boundaries between the NFP, for-profit and public sectors, has resulted in the social enterprise construct becoming a force for change by which both NFP and for-profit organisations can attempt to gain and maintain legitimacy. The Big Society is arguably the first signal by the UK Coalition Government of its belief that the current relationship between the state and the market has failed. However, the Big Society agenda has significant unintended consequences for SEOs involved in the provision of public services. These include the risk of mission drift, the blurring of accountabilities for public services and the crowding out of social enterprise and NFPOs. Each of these is now discussed.

\section{Risk of Mission Drift}

Neither side of the public-private partnership appears able to provide all the public services required in modern society, with the consequence that NFPOs are being asked to fill this void. Also, policy pressures, including the contracting out of public services, are forcing NFPOs to become more business-like and generate income through the social enterprise model. However, in doing so, these organisations risk 'mission drift' in terms of their public benefit objectives. Furthermore, if NFPOs move away from their traditional role questions arise as to whether the traditional public benefit functions provided by NFPOs will be threatened due to capacity constraints. Cairns, Harris and Young (2005) draw attention to the challenges of building capacity in NFPOs as they are drawn ever more closely into the delivery of public services. These include maintaining organisational distinctiveness and independence, together with developing the necessary skills for both new services and determining organisational strategy.

SEOs are central to the UK Coalition Government's plans for public reform and the creation of the Big Society. The widescale reductions in public expenditure in the UK and Republic of Ireland present both opportunities and challenges for SEOs. For example, as a result of policy initiatives designed to encourage a greater role 
for SEOs in providing mainstream public services, the boundaries between SEOs and other types of organisation have become increasingly blurred. The government's widespread use of NFPOs to deliver a growing variety of public services has raised questions about the continuity and sustainability of the NFP sector in its current form and has led to calls for greater accountability. The evolving role of the state from provider to enabler has increased calls for NFPOs to report information about their performance (outputs and outcomes) to facilitate benchmarking of costs and effectiveness. Eikenberry (2009) warns of the risks for NFPOs of being colonised by the market and suggests that adopting the discourse of the market will not encourage more deliberate or participatory democracy in NFPOs. Moreover, there is a danger that the pressure to formally discharge accountability externally may discourage traditional NFP sector supporters and volunteers from embracing the social enterprise concept and the Big Society agenda.

\section{Blurring of Accountabilities for Public Services}

Policy pressures for change within the NFP sector through increased use of the social enterprise model is a key feature of the Big Society agenda. However, there are strong counter-pressures on NFPOs to resist change, safeguard their distinctive characteristics and defend their organisational boundaries, especially as there is a danger that established NFPOs become junior partners with for-profit organisations in the provision of public services. There is a real possibility that as NFPs and forprofits converge a blurring of accountabilities for public services will begin to occur. Such lack of clarity becomes more problematic if service provision is fragmented (which might easily occur if one neighbourhood's priorities differ from those of another) or the service providers fail, thus calling into question the subsequent role and responsibilities of the state. Moreover, while the Open Public Services White Paper promises accountability through choice and decentralisation, the mechanisms required to achieve this could mean multiple layers of audit, inspection and oversight. In addition, the perceived enthusiasm for direct, local involvement may prove unrealistic, particularly in the longer term.

\section{Crowding Out of Social Enterprise and Not-for-Profit Organisations}

The for-profit sector cannot be divorced from discourses on the Big Society since it encourages for-profit organisations to engage more fully with society and government. At a point when the reputation of for-profit organisations is at an all-time low, they are being pushed to integrate social issues into their business strategies and put the same focus into social issues as they do brands and customers. At the same time as the Big Society is promoting a much bigger role for SEOs in the delivery of public services, legitimation pressures, augmented by the current financial crisis, are leading for-profit organisations to be more overtly socially responsible. However, there is a real risk that these organisations will crowd out genuine SEOs in terms of capacity and financial resources and the Big Society idea will be dominated by Big Business. On the other hand, if for-profit organisations do not genuinely engage with social enterprise, this may not only damage their longerterm reputation in the eyes of salient stakeholders but also the concept of social enterprise. 
Alcock (2010, p. 384) suggests that the use of NFPOs to compensate for reduced welfare spending is predicated on the assumption that public welfare provision has 'crowded out' voluntary action. Bubb (2010) argues that detailed policy planning is required for the Big Society to move from romanticism to reality. Although the Big Society, as a model of social change, is presented as a solution to the problem of both 'corporate' and 'moral' decline, together with the inflexibility of 'big government', it could be argued that what government is really intent on doing is reducing the size of the public sector. Furthermore, the strategic unity of the NFP sector is being formally challenged as discourse moves to ideas around the Big Society and, as critics from the NFP sector have pointed out, there is a serious risk that in the new 'volunteer society' people in disadvantaged communities will become even more marginalised since they are unlikely to have the personal and financial resources necessary for volunteering. Arguably, transforming lives through transforming communities requires more resources. For some, the expansion of social enterprise into mainstream services is an important part of the policy of reducing the role of the state in direct service provision. For others, this will lead to the fragmentation of service provision, an over-reliance on for-profit providers, the undermining of trade unions and central bargaining, and a reduction in public accountability for those services.

\section{CONCLUSION}

Consistent with the concepts of social action and civil society advanced by Burke (1790), there "is a challenge to build the "little society", rather than the "Tesco" type organisations that are skilled at tendering' (House of Commons, 2012, p. 7). The private sector is expected to play a major role in generating economic recovery, and there is a need to forge new relationships between NFP and for-profit organisations in order to achieve the Big Society vision. This will need to extend far beyond current corporate social responsibility into genuinely meaningful partnerships based on new (and old) ways of working. As a way forward, the formation of new social-private partnerships might facilitate the scaling up of operations and attract additional sources of finance. Such a hybrid, partnership-based relationship could harness the best of the for-profit sector to underpin a substantial expansion of social enterprise activity aimed at delivering significant social and environmental objectives. For some SEOs there will be a fear of losing independence or being pushed aside once a contract is won. As boundaries become increasingly blurred between the NFP, for-profit and public sectors, the time may now be right for the coming together of these sectors to deliver public services. To do otherwise will seriously undermine the ethos underpinning the Big Society and, instead of protecting and enhancing the delivery of public services, proposed public sector reforms will create an unequal playing field in which SEOs are unable to compete with large privatesector providers masquerading as socially responsible businesses. Moreover, there is a danger that under the Big Society agenda SEOs will become agents of public policy, subject to targets and incentives, and therefore an extension of the state. 
(Un)Intended Consequences of the Big Society for Social Enterprise Organisations

\section{NOTES}

1 The distinction between a not-for-profit organisation (NFPO), non-governmental organisation (NGO) and a charity is often imprecise (Vakil, 1997; Martens, 2002). In broad terms, a NFPO (also referred to as a nonprofit organisation) is an organisation that does not distribute its surplus funds to owners or shareholders, but instead uses them to help pursue its goals. NFPOs include NGOs and charities. While most governments and their agencies meet the definition of a NFPO, they are usually considered a separate type of organisation and not counted as NFPOs. An NGO is a non-profit, voluntary group. NGOs perform a variety of services and humanitarian functions, bring citizens' concerns to governments, advocate and monitor policies, and encourage political participation through provision of information. A charity is a NFPO that meets stricter criteria regarding its purpose and the way in which it makes decisions and reports its finances.

2 For a fuller discussion on the UK charity sector, including its size and issues associated with accounting, accountability and governance, see Connolly, Hyndman and McConville (2011) and Connolly, Dhanani and Hyndman (2013).

3 Renamed the Office for Civil Society following the 2010 general election, with responsibility for charities, social enterprises and voluntary organisations in the Cabinet Office.

\section{REFERENCES}

Aakhus, M. and Bzdak, M. (2012). Revisiting the Role of 'Shared Value' in the Business Society Relationship, Business and Professional Ethics Journal, Vol. 31, No. 2, pp. 231-246.

Aiken, M. (2006). Towards Market or State? Tensions and Opportunities in the Evolutionary Path of Three UK Social Enterprises, in M. Nyssens (ed.), Social Enterprise at the Crossroads of Market, Public and Civil Society, London: Routledge.

Alcock, P. (2010). Building the Big Society: A New Policy Environment for the Third Sector in England, Voluntary Sector Review, Vol. 1, No. 3, pp. 379-389.

Alcock, P. (2011). Voluntary Action, New Labour and the 'Third Sector', in M. Hilton and J. McKay (eds), The Ages of Voluntarism: How We Got to the Big Society, Oxford: Oxford University Press/British Academy.

Alcock, P. and Kendal, J. (2011). Constituting the Third Sector: Processes of Decontestation and Contention under the UK Labour Governments in England, Voluntas: International Journal of Voluntary and Nonprofit Organizations, Vol. 22, No. 3, pp. 450-469.

Bird, P. and Morgan-Jones, P. (1981). Financial Reporting by Charities, London: Institute of Chartered Accountants in England and Wales.

Bubb, S. (2010). The Big Society: Moving from Romanticism to Reality, London: Association of Chief Executives of Voluntary Organisations.

Burke, E. (1790). Reflections on the Revolution in France, available from: <http:/ / www.constitution.org/eb/rev_fran.htm>, accessed 14 March 2012.

Cabinet Office (2010). Building a Stronger Civil Society: A Strategy for Voluntary and Community Groups, Charities and Social Enterprises, London: Cabinet Office.

Cairns, B., Harris, M. and Young, P. (2005). Building the Capacity of the Voluntary Nonprofit Sector: Challenges of Theory and Practice, International Journal of Public Administration, Vol. 28, Nos. 9-10, pp. 869-885.

Cameron, D. (2009a). Putting Britain Back on Her Feet, speech at the Conservative Party Conference in Manchester, 8 October, available from: <http://www.theguardian.com/ politics/2009/oct/08/david-cameron-speech-in-full>, accessed 28 May 2013.

Cameron, D. (2009b). Big Society Can Fight Poverty. Big Government Just Fuels It, The Guardian, 11 November, p. 30.

Chang, H. (2011). 23 Things They Don't Tell You about Capitalism, London: Penguin Books. 
Connolly and Kelly

Connolly, C., Dhanani, A. and Hyndman, N. (2013). The Accountability Mechanisms and Needs of External Charity Stakeholders, Research Report 132, London: The Association of Chartered Certified Accountants.

Connolly, C., Hyndman, N. and McConville, D. (2011). Research in Charity Accounting and Reporting: A Fertile Field for Exploration, Irish Accounting Review, Vol. 18, No. 2, pp. 6-28.

Co-operatives UK (2010). The Formula for Co-Operation, Manchester: Co-operatives UK.

Dart, R. (2004). The Legitimacy of Social Enterprise, Non-Profit Management \& Leadership, Vol. 14, No. 4, pp. 411-424.

Dees, G. (1998). Enterprising Non-Profits: What Do You Do When Traditional Sources of Funding Fall Short?, Harvard Business Review, January-February, Vol. 76, No. 1, pp. 54-67.

DeFilippis, J. (2001). The Myth of Social Capital in Community Development, Housing Policy Debate, Vol. 12, No. 4, pp. 781-806.

Defourny, J. and Nyssens, M. (2006). Defining Social Enterprise, in M. Nyssens (ed.), Social Enterprise at the Crossroads of Market, Public and Civil Society, London: Routledge.

Department of Trade and Industry (2002). Social Enterprise: A Strategy for Success, London: Department of Trade and Industry.

DiMaggio, P. and Powell, W.W. (1983). The Iron Cage Revisited: Institutional Isomorphism and Collective Rationality in Organisational Fields, American Sociological Review, Vol. 48, No. 2, pp. 147-160.

Edwards, M. (2008). Just Another Emperor? The Myths and Realities of Philanthrocapitalism, London: Demos.

Eikenberry, A. (2009). Refusing the Market: A Democratic Discourse for Voluntary and Nonprofit Organisations, Nonprofit and Voluntary Sector Quarterly, Vol. 38, No. 4, pp. 582-596.

Eikenberry, A. and Kluver, J. (2004). The Marketisation of the Nonprofit Sector: Civil Society at Risk?, Public Administration Review, Vol. 64, No. 2, pp. 132-140.

Evers, A. (2010). Observations on Incivility: Blind Spots in Third Sector Research and Policy, Voluntary Sector Review, Vol. 1, No. 1, pp. 113-119.

Friedman, M. (1962). Capitalism and Freedom, Chicago, IL: University of Chicago Press.

Giddens, A. (1998). The Third Way: The Renewal of Social Democracy, Oxford: Policy Press.

Gover, C. (2009). The Third Way: A Compromise of the Left? New Labour, the Independent Labour Party and Making Work Pay, Policy \& Politics, Vol. 37, No.1, pp. 3-18.

Harding, R. (2010). Hidden Social Enterprises: Why We Need to Look Again at the Numbers, London: Delta.

Hardy, R. (2004). Social Enterprise: The New Economic Engine, Business Strategy Review, Vol. 15 , No. 4, pp. 39-43.

Haugh, H. and Kitson, M. (2007). The Third Way and the Third Sector: New Labour's Economic Policy and the Social Economy, Cambridge Journal of Economics, Vol. 31, No. 6, pp. 973-994.

Hood, C. (1995). The 'New Public Management' in the 1980s: Variations on a Theme, Accounting, Organizations and Society, Vol. 20, No. 3, pp. 93-109.

House of Commons (2012). The Big Society: Report by the Public Administration Select Committee, Seventeenth Report of Session 2010-12, London: The Stationery Office.

Kerlin, J.A. (2010). A Comparative Analysis of the Global Emergence of Social Enterprise, Voluntas: International Journal of Voluntary and Nonprofit Organisations, Vol. 21, No. 2, pp. 162-179.

KPMG (2011). Department of Enterprise, Trade and Investment: Social Economy Evaluation Assignment, Belfast: KPMG.

Martens, K. (2002). Mission Impossible? Defining Nongovernmental Organisations, Voluntas: International Journal of Voluntary and Nonprofit Organisations, Vol. 13, No. 3, pp. 271-285. 
(Un)Intended Consequences of the Big Society for Social Enterprise Organisations

Meyer, J. and Rowan, B. (1977). Institutional Organisations: Formal Structure as Myth and Ceremony, American Journal of Sociology, Vol. 83, No. 2, pp. 340-363.

Murtagh, B., Goggin, N. and McCrum, J. (2014). The Social Economy in Northern Ireland, Belfast: Queen's University Belfast.

Newman, J. (2007). Re-Thinking 'The Public' in Troubled Times: Unsettling State, Nation and the Liberal Public Sphere, Public Policy and Administration, Vol. 22, No. 1, pp. 27-47.

Nicholls, A. (2006). Social Entrepreneurship: New Paradigms of Social Sustainable Social Change, Oxford: Oxford University Press.

Norman, J. (2010). The Big Society: The Anatomy of the New Politics, Buckingham: University of Buckingham Press.

Open Public Services and Cabinet Office (2011). Open Public Services White Paper, Cm8145, London: The Stationery Office.

Patulny, R. (2004). Bonding, Bridging and Investment: Important Aspects of a National Social Capital Policy Strategy, Melbourne Journal of Politics, Vol. 29, pp. 68-81.

Peattie, K. and Morley, A. (2008). Social Enterprises: Diversity and Dynamics, Contexts and Contributions, Cardiff: Economic and Social Research Council (ESRC)/Centre for Business Relationships, Accountability, Sustainability and Society (BRASS) Research Centre.

Pharoah, C., Scott, D. and Fisher, A. (2004). Social Enterprise in the Balance: Challenges for the Voluntary Sector, London: Charities Aid Foundation.

Porter, M.E. and Kramer, M.R. (2011). Creating Shared Value: How to Reinvent Capitalism - and Unleash a Wave of Innovation and Growth, Harvard Business Review, Vol. 89, Nos. 1/2, January-February, pp. 62-77.

Putnam, R. (1995). Bowling Alone: America's Declining Social Capital, Journal of Democracy, Vol. 6, No. 1. pp. 65-78.

Ridley-Duff, R. (2008). Social Enterprise as a Socially Rational Business, International Journal of Entrepreneurial Behaviour and Research, Vol. 14, No. 5, pp. 291-312.

Salamon, L.M. (1995). Partners in Public Service: Government-Nonprofit Relations in the Modern Welfare State, Baltimore, MD: Johns Hopkins University Press.

Scott, W.R. (1995). Institutions and Organisations: Ideas, Interests, and Identities, Thousand Oaks, CA: Sage Publications.

Seanor, P. and Meaton, J. (2007). Learning from Failure, Ambiguity and Trust in Social Enterprise, International Journal of Entrepreneurial Behaviour and Research, Vol. 14, No. 5, pp. 291-312.

Smerdon, M. (2009). The First Principle of Voluntary Action: Essays on the Independence of the Voluntary Sector in Canada, England, Germany, Northern Ireland, Scotland, United States of America and Wales, London: The Baring Foundation.

Social Enterprise Coalition (2011). Social Enterprise FAQs, Social Enterprise UK, available from: <http://www.socialenterprise.org.uk/pages/frequently-asked-questions.html>, accessed 16 February 2012.

Strategy Unit (2002). Private Action, Public Benefit: A Review of Charities and the Wider Not-forProfit Sector, London: Cabinet Office.

Suchman, M. (1995). Managing Legitimacy: Strategic and Institutional Approaches, Academy of Management Review, Vol. 20, No. 3, pp. 571-610.

Tarrow, S. (1996). Making Social Science Work across Space and Time: A Critical Reflection on Putnam's Making Democracy Work, American Political Science Review, Vol. 90, No. 2, pp. 389-397.

Teasdale, S. (2010a). Explaining the Multifaceted Nature of Social Enterprise: Impression Management as (Social) Entrepreneurial Behaviour, Voluntary Sector Review, Vol. 1, No. 3, pp. 271-292. 
Connolly and Kelly

Teasdale, S. (2010b). Social Enterprise: Discourses, Definitions and (Research) Dilemmas, Paper Presented to $3^{\text {rd }}$ Social Entrepreneurship Research Colloquium, 22 June, University of Oxford.

Tsakalotos, E. (2005). Homo Economicus and the Reconstruction of Political Economy: Six Theses on the Role of Values in Economics, Cambridge Journal of Economics, Vol. 29, No. 6, pp. 893-908.

Vakil, A.C. (1997). Confronting the Classification Problem: A Taxonomy of NGOs, World Development, Vol. 25, No. 12, pp. 2057-2070. 